\title{
Tariffs, Trade and Economic Growth in a Model with Institutional Quality
}

\section{Azam Chaudhry*}

\begin{abstract}
This article shows how institutional quality can affect the relationship between trade and growth. Our model looks at an economy in which the export sector is a high-innovation sector. In this economy, a government that is politically threatened by innovation can use its tariff policy to block innovation and increase domestic revenues. In this case, higher tariffs reduce economic growth and the government faces a tradeoff: It can either (i) raise tariffs, collect greater rents, and increase stability; or (ii) it can reduce tariffs and increase longrun growth and instability. When the quality of a country's institutions are reflected in the costs of increasing tariffs, it can be shown that countries with strong institutions gain more (in terms of growth) from trade than countries with weak institutions, due to the effect of institutions on trade policy. It is also possible to show that the quality of institutions in one country can spill over into another by affecting its trading partner's growth rate of income. However, these results are reversed in the case where a country has a highly innovative domestic sector-this explains the tariff-growth paradox in which countries experience higher growth with higher tariffs in earlier stages of development, but higher growth with lower tariffs in later stages of development.
\end{abstract}

Keywords: Economic growth, institutions, trade, tariffs.

\section{JEL Classification: O41, O43, E1, F13.}

\section{Introduction}

This study provides a new link between institutions, tariffs, and growth. More specifically, it shows how the quality of a country's institutions helps determine the tariff level set in the economy. This tariff level, in turn, influences the economy's rate of growth. Though institutions can sometimes be used for very specific aspects of an economy, we use the general definition of institutions provided by North (1990):

\footnotetext{
* Associate Professor of Economics, Lahore School of Economics, Pakistan.
} 
Institutions are the rules of the game in a society or, more formally, are the humanly devised constraints that shape human interaction. In consequence they structure human incentives in human exchange, whether political, social or economic.

Thus, institutional quality will measure (i) the quality of formal rules (such as property rights, the legal system, etc.) and informal rules (such as trust and conventions) in an economy; and (ii) the impact of these rules on determining trade policy.

Economists such as North (1990) have discussed the effect of institutional quality on a country's growth rate, and many others have established the empirical link (see Acemoglu, Johnson, \& Robinson, 2001; Barro, 1997; Knack \& Keefer, 1995), but the effect of institutions on tariff policy has been relatively neglected. Some economists have analyzed the relationship from a political perspective: Hillman (1982) discusses political support-maximizing protectionist responses for declining industries. Another well-known analysis is by Grossman and Helpman (1994), who model the structure of trade protection to reflect the outcome of a competition for political favors.

Though these models focus on the political reasons for the level of protection set by a country's government, they can also be viewed as specific institutional explanations for a government's trade policy formulation. Thus, the size, influence, or contributions from lobbying are just one piece of the entire institutional puzzle that explains why governments raise or lower tariffs.

What makes our model different is that institutional quality plays a key role in determining the level of tariffs that are set in an economy. More specifically, a country with stronger institutions bears higher "costs" of tariffs than a country with weaker institutions. These costs can be seen in two ways: (i) a country with strong institutions might have a more efficient direct tax collection and enforcement mechanism, which makes the relative cost of tariff collection higher; or (ii) the costs of imposing tariffs can be seen as political costs, in which a government with better institutions is more apt to respond to domestic and foreign pressures for free trade. In this paper, no matter which interpretation is used, we expect countries with better institutions to have lower tariff levels. 
Graphical evidence of this relationship is shown in Figure 1 (Appendix B), which plots the relationship between the effective tariff rate (taken from the Sachs \& Warner, 1995, dataset) and institutional quality (taken from the International Country Risk Guide's corruption index) across countries. The figure suggests that there may be a negative relationship between tariffs and institutions-the correlation coefficient between the two variables is -0.57 ; if one excludes India (which has very high tariffs) as an outlier, then the correlation coefficient rises to -0.70 .

However, it is important to note that this correlation does not automatically prove causation: a better functioning legal system may improve tax collection, which could lead to lower tariff rates. Similarly, lower tariff rates may lead to greater competition, in turn leading to improved institutions. In actuality, both channels exist, and separating the impact of the two is an interesting exercise. But the scope of this article is limited to looking at how improved institutional quality affects a government's determination of tax policy, which, in turn, impacts innovation and economic growth.

The second economic relationship modeled in this study is that between tariffs and growth. The oft-quoted Sachs-Warner (1995) results imply that openness (or lower protection) affects growth positively, but this has come under some scrutiny by Rodriguez and Rodrik (1999). Since then, Clemens and Williamson (2001) have weighed in on the side of Sachs and Warner, and found that the relationship between tariffs and growth was negative for the last three decades. But their findings-preceded by similar results by O'Rourke (2000) - present another problem: While, in recent times, higher tariffs may have been accompanied by lower growth, higher tariffs were accompanied by higher growth in the late 19th and early 20th centuries. This is illustrated in Figure 2 (Appendix B). What is the difference now as compared to the past?

Our model explains this "tariff-growth paradox" as follows. What higher tariffs basically do is reallocate labor from the export sector to the domestic production sector. Now, if the export sector was predominantly made up of agricultural or basic manufactured goods, then a reallocation of labor out of the export sector would lead to more labor going into high productivity research in the domestic sector. This, in turn, would lead to more innovations and higher growth. Thus, if higher tariffs reallocate labor from a low-innovation export sector to a higher-innovation domestic sector, then higher tariffs will lead to higher growth. 
On the other hand, if the export sector was the higher-innovation sector, then higher tariffs would lead to labor moving out of the highinnovation sector and into the low-innovation sector, thus reducing growth. One explanation for the "tariff growth paradox" could therefore be that, in the late 19th century, higher tariffs led to labor being pushed into higher-innovation domestic industries. But in the late 20th century, with greater trade links, the export sector had become the higher-innovation sector. Thus, growth would be reduced if tariffs were raised. This idea is supported by Broadberry (1998), who finds that the shift of resources out of agriculture can account for significant productivity growth in countries such as Germany, the UK, and the US in the late 19th century.

Thus, institutions help determine tariffs and, in turn, tariffs help determine growth. But there is one more aspect to the model: Tariffs not only generate revenue for the government, they can also be viewed as political tools for reducing political instability. Recent work by Chaudhry and Garner $(2006,2007)$ and earlier work by Dinopoulos and Syropoulos (1999) has focused on how innovation is capable of politically destabilizing a government.

The model we present here yields a way in which tariffs can be used to (i) block innovation, and (ii) increase political stability. The first can be achieved by reducing the amount of competition faced by the domestic sector, reducing the need for these sectors to innovate. The second, political stability, can be brought about by protecting the interest of economic elites, which would increase the chances for reelection (see Grossman \& Helpman, 1994). Thus, higher tariffs can either increase political stability either by blocking innovation or by increasing the chances of reelection. The model shows how institutional quality and tariffs affect a country's growth rate, and presents an interesting idea of institutional spillovers in which institutions influence a country's tariff policy, which in turn affects the growth rates of its trading partners.

Section 2 explains the model in question, Section 3 presents its results, and Section 4 concludes the article.

\section{The Model}

Our model is an extension of the "tariffs and Schumpeterian growth" model of Dinopoulos and Syropoulos (1997), ${ }^{1}$ and presents a dynamic two-country and three-commodity model of Schumpeterian

\footnotetext{
${ }^{1}$ Dinopoulos and Segerstrom (1999) present a similar model.
} 
growth (see also Aghion \& Howitt, 1992, 1999), trade, and tariffs. Section 2.1 describes the basic Dinopoulos and Syropoulos model, while Section 2.2 extends this basic model by adding to it a government "welfare function" through which the tariff rate set on imports is endogenously determined. We go on to examine the effect of tariff reductions on longrun growth rates, and then compare these changes in growth rates across countries with differing qualities of institutions.

\subsection{The Basic Dinopoulos and Syropoulos (1997) Model}

The basic model contains two countries, denoted by superscripts $i$ $=1,2$. Each country comprises three sectors, denoted by subscripts $j=0$, 1, 2, each producing one good: (i) a nontraded good, denoted by the subscript $j=0$, in which there are endogenous process innovations due to research and development (R\&D); (ii) a traded good, 1, denoted by subscript $j=1$, for which endogenous process innovations due to R\&D occur only in country 1 and not in country 2-thus, only country 1 produces that good; and (iii) a traded good, denoted by subscript $j=2$, for which endogenous process innovations due to R\&D occur only in country 2 and not in country 1 -thus, only country 2 produces that good.

The assumptions above imply that country 1 has a comparative advantage in the production of good 1, whereas country 2 has a comparative advantage in the production of good 2. Additionally, we assume that there are no technological spillovers from country 1 to country 2 in sector 1 (or from country 2 to 1 in sector 2 ). ${ }^{2}$

Comparative advantage would dictate that each country should eventually specialize in the production of the good in which it has a comparative advantage. Even if country $i$ imposed a tariff on imports of good $j$ (to protect its inefficient $j$ sector), eventually foreign innovations would push the tariff-inclusive price of the imported good below the price of the good produced domestically. Thus, the assumption of complete specialization is made with country 1 producing the world output of good 1 and country 2 producing the world output of good 2 .

The pattern of trade in this model is that country 1 produces good 0 domestically and consumes the final output; it also produces good 1 domestically, consumes a certain amount, and exports the rest to country 2.

\footnotetext{
2 The model's results would remain the same if one were to assume that country $i$ was not at the frontier of technology in the production of good $j$, which would mean that it was at least one innovation behind country $j$ in the good $j$ sector.
} 
The only primary factor of production in the model is labor, which, in each country, can be used to produce final output and provide $R \& D$ services. The latter result in random discoveries of better production methods that improve the productivity of the labor used to produce final goods.

For simplicity, the model is set up for country 1 (represented by the superscript 1). Analogous setup, market-clearing conditions, and steady state solutions can be obtained for country 2 . The inter-temporal utility function of the representative consumer in country 1 is

$$
U^{1}=\int_{0}^{\infty} e^{-\rho t} \ln \left(u^{1}(t)\right) d t
$$

The term $\rho>0$ is a constant discount rate, and $\ln \left(u^{1}(t)\right)$ is the consumer's instantaneous utility. Additionally,

$$
u^{1}(t)=\prod_{j=0}^{2}\left[d_{j}^{1}(t)\right]^{\alpha_{j}}
$$

Here $\alpha_{j}>0, \sum_{j=0}^{2} \alpha_{j}=1$ and $d_{j}^{1}(t)$ is the quantity of good $j$ demanded by the representative consumer in country 1 at time $t$.

At time $t$, the instantaneous expenditure per consumer in country 1 across all goods is $E^{1}(t) E$. Solving the consumer's static optimization problem, we obtain

$$
d_{j}^{1}(t)=\alpha_{j} E^{1}(t) / p_{j}^{1}(t) \quad \forall j=0,1,2
$$

$p_{j}^{1}(t)$ is the price of good $j$ in country 1 at time $t$.

If the labor force in country 1 is equal to $\mathrm{L}^{1}$, the aggregate demand for $\operatorname{good} j$ in country 1 is:

$$
D_{j}^{1}(t)=L^{i} d_{j}^{1 i}(t)
$$

Consumers maximize their expected discounted lifetime utility, so solving their inter-temporal optimization problem yields

$$
\dot{E} / E^{1}(t)=r^{1}(t)-\rho
$$

where $r^{1}(t)$ is the instantaneous interest rate of country 1 . 
Let $q_{j}(t)$ denote the world price of good $j$ at time $t$, and $T_{j}^{1}(t)$ denote the ad-valorem tariff levied by country 1 on its imports. At this point, we make the assumption that neither country's government levies any tariffs or taxes on its own nontraded good or exported good. The domestic price of country 1's imported good is

$$
p_{j}^{1}(t)=T_{j}^{1}(t) q_{j}(t), \text { where } T_{j}^{1}(t)=\left(1+\tau_{j}^{1}(t)\right)
$$

Defining $Y_{j}^{1}(t)$ as country 1 's expenditure on $\operatorname{good} j$, and $Y_{j}(t)=$ $\sum_{\epsilon N} Y_{j}^{i}(t)$ as the world's expenditure on good $j$ as a whole (both measured in world prices), we can use Equation (3) to obtain

$$
\begin{aligned}
& q_{j}(t) D_{j}^{1}(t)=\alpha_{j} L^{1} E^{1}(t) / T_{j}^{1}(t)=Y_{j}^{1}(t) \quad \forall_{j}=0,1,2 \\
& q_{j}(t)\left[\sum_{h \in N} D_{j}^{h}(t)\right]=Y_{j}(t)
\end{aligned}
$$

An important feature of the model is that it assumes Bertrand competition, which results in limit-pricing strategies-the monopolist does not charge monopoly prices, but instead a price just low enough to drive out holders of less quality intermediates. Let $X_{j}^{1}$ denote the output of good $j$ in country 1 , and $v(1, j) \in\{0,1,2 \ldots\}$ denote the number of innovations that have occurred in sector $j$ of country 1 . If $\gamma_{j}>1$ represents the increment in labor productivity per innovation in sector $j$, and $L_{j}^{1}$ represents the labor allocated to manufacturing in sector $j$ in country 1 , the following are the production functions for the final goods:

$$
X_{j}^{1}=\left\{\begin{aligned}
\gamma_{j}^{1+v(1, j)} L_{j}^{1} & \text { if } j=0,1 \\
L_{j}^{1} & \text { if } j \neq 0,1 \quad \text { where } \gamma_{j}^{1+v(1, j)}>0
\end{aligned}\right.
$$

This equation implies that country 1 could utilize one unit of labor to produce $\gamma_{0}^{1+v(1,0)}$ units of the nontraded good $(0)$, or $\gamma_{1}^{1+v(1,1)}$ units of the exported good (1). The country could also use one unit of labor to produce one unit of good 2 . This implies that country 1 has a comparative advantage in producing good 1 for all time periods.

From this we can determine the profits of country 1's monopolists in the nontraded good (0) and the export good (1).

$$
\pi_{0}^{1}=\left[p_{0}^{1}-\omega^{1} / \gamma_{0}^{1+v(1,0)}\right] D_{0}^{1}
$$




$$
\pi_{1}^{1}=\left[q_{1}(t)-\omega^{1} / \gamma_{1}^{1+v(1,1)}\right]\left[\sum_{h \in N} D_{1}^{h}\right]
$$

Given that $p_{0}^{1}=\omega^{1} / \gamma_{0}^{1+v(1,0)}$ and $q_{1}(t)=\omega^{1} / \gamma_{1}^{1+v(1,1)}$, we can use Equations (5) and (7) to rewrite the profit functions as

$$
\begin{aligned}
& \pi_{0}^{1}=\left[1-1 / \gamma_{0}\right] p_{0}^{1} D_{0}^{1}=\left[1-1 / \gamma_{0}\right] Y_{0}^{1} \\
& \pi_{1}^{1}=\left[1-1 / \gamma_{1}\right] q_{1}\left[\sum_{h \in N} D_{1}^{h}\right]=\left[1-1 / \gamma_{1}\right] Y_{1}
\end{aligned}
$$

In addition to devoting labor to final production, each country devotes labor to R\&D to improve labor productivity. The model assumes that there is free entry into the R\&D race, or that workers are employed in R\&D up until its expected gains equal its expected costs. In country 1 , the $k^{\text {th }}$ firm producing good $j$ devotes $n_{j k}^{1}$ units of labor to R\&D, with the sector-wide quantity of labor devoted to $\mathrm{R} \& \mathrm{D}$ equal to $n_{j}^{1}=\sum_{k} n_{j k}^{1}$. Each unit of labor devoted to $R \& D$ has a constant productivity of $\lambda$, which does not vary across goods. It is important to note that the expected instantaneous profits are not dependent on either time or the number of innovations in that sector. Thus, each firm in country 1 , producing good $j$, devotes $R_{j k}^{1}$ units of R\&D services, where

$$
\begin{aligned}
& R_{j k}^{1}=\lambda n_{j k}^{1} \\
& R_{j}^{1}=\sum_{k} R_{j k}^{1}
\end{aligned}
$$

Note that the second equation above is the total quantity of labor services devoted to R\&D for the production of good $j$ in country 1.

If the arrival of innovations in each sector follows a Poisson process, the instantaneous probability of successful innovation occurring in sector $j$ (of country 1 ) will be equal to $R_{j}^{1} d t$. Similarly, the instantaneous probability of firm $k$ discovering a state-of-the-art innovation is $R_{j k}^{1} d t$. Based on this, the expected profit of a firm participating in the $R \& D$ race in sector $j$ of country 1 is

$$
\left[\frac{\pi_{j}^{1}}{r^{1}+R_{j}^{1}}\right]\left[R_{j k}^{1} d t\right]-w^{1}\left[n_{j k}^{1}\right] d t
$$

This reduces to:

$$
\left[\frac{\pi_{j}^{1}}{r^{1}+R_{j}^{1}}\right]=\frac{w^{1}}{\lambda}
$$


Combining Equations (11) and (8) yields the following expressions for the quantity of labor devoted to R\&D in each sector $(j)$ of country 1 :

$$
\begin{aligned}
& n_{0}^{1}=R_{0}^{1} / \lambda=\left[1-1 / \gamma_{0}\right]\left[Y_{0}^{1} / w^{1}\right]-\rho / \lambda \\
& n_{1}^{1}=R_{1}^{1} / \lambda=\left[1-1 / \gamma_{1}\right]\left[Y_{1} / w^{1}\right]-\rho / \lambda
\end{aligned}
$$

where $n_{0}^{1}$ is the amount of labor devoted to R\&D for the production of good 0 by country 1 , and $n_{1}^{1}$ is the amount of labor devoted to R\&D for the production of good 1 by country 1 . Recall that there is no R\&D investment for the production of good 2 by country 1 (or $n_{2}^{1}=0$ ).

Each country has perfectly competitive labor markets, ensuring that the wage rate adjusts to equate labor supply to labor demand. It can be shown that, in country 1 , the amounts of labor devoted to the final production of the nontraded good ( 0$)$ and the exported good $(i)$ are equal to $L_{0}^{1}=\left[1 / \gamma_{0}\right]\left[Y_{0}^{1} / w^{1}\right]$ and $L_{1}^{1}=\left[1 / \gamma_{1}\right]\left[Y_{1}^{1} / w^{1}\right]$ respectively. Thus, full employment in country 1 's labor market dictates that

$$
n_{0}^{1}+n_{1}^{1}+\left[1 / \gamma_{0}\right]\left[Y_{0}^{1} / w^{1}\right]+\left[1 / \gamma_{1}\right]\left[Y_{1} / w^{1}\right]=L^{1}
$$

Substituting Equations (12) into (13), we obtain

$$
\left[Y_{0}^{1} / w^{1}\right]+\left[Y_{1} / w^{1}\right]=L^{1}+2 \rho / \lambda
$$

In steady state, $r_{i}(t)=\rho$ in Equation (4). We assume that each country's trade account is balanced at every point in time. This implies that

$$
\sum_{h=0,1}\left(q_{1} D_{1}^{h}\right)=\left(q_{2} D_{2}^{1}\right)
$$

By adding $q_{1} D_{1}^{1}$ to each side and substituting in Equations (5), this can be transformed into

$$
\begin{aligned}
& \sum_{h \in N}\left(q_{1} D_{1}^{h}\right)=\sum_{j \neq 0}\left(q_{j} D_{j}^{1}\right), \text { which implies that: } \\
& Y_{1}=\sum_{j \neq 0} Y_{j}^{1}
\end{aligned}
$$

This states that world expenditure on country 1's exported good is equal to country 1's expenditure on all traded goods.

Using the first line in Equation (5a), Equation (16) can be rewritten as 


$$
Y_{0}^{1} / w^{1}=\left[\varphi^{1} / \alpha_{0}\right]\left[Y_{1} / w^{1}\right] \text { where } \varphi^{1}=\sum_{j \neq 0} \alpha_{j} / T_{j}
$$

In the equation above, $\varphi^{1}$ can be interpreted as the degree of trade liberalization in country 1 . If $\varphi^{1}>\varphi^{2}$, this implies that country 1 has lower tariffs-and a more liberal trade regime-than country 2.

Solving Equations (14) and (17) simultaneously, we obtain

$$
\begin{aligned}
& Y_{0}^{1} / w^{1}=\left[\alpha_{0} /\left(\alpha_{0}+\varphi^{1}\right)\right]\left[L^{1}+2 \rho / \lambda\right] \\
& Y_{1} / w^{1}=\left[\varphi^{1} /\left(\alpha_{0}+\varphi^{1}\right)\right]\left[L^{1}+2 \rho / \lambda\right]
\end{aligned}
$$

The further substitution of Equations (18) into Equations (12) yields

$$
\begin{aligned}
& R_{0}^{1}=\lambda\left[1-1 / \gamma_{0}\right]\left[\alpha_{0} /\left(\alpha_{0}+\varphi^{1}\right)\right]\left[L^{1}+2 \rho / \lambda\right]-\rho \\
& R_{1}^{1}=\lambda\left[1-1 / \gamma_{1}\right]\left[\varphi^{1} /\left(\alpha_{0}+\varphi^{1}\right)\right]\left[L^{1}+2 \rho / \lambda\right]-\rho
\end{aligned}
$$

In the steady-state equilibrium described above, total consumption expenditures, R\&D investment, and the inter-sectoral allocation of labor remain constant. Sequential $R \& D$ races result in the discovery of better $R \& D$ techniques. These innovations increase both the productivity of workers in the production of final goods and their output, which is matched by instantaneous reductions in the price of final goods.

For consumers, these reductions in price lead to perpetual increases in their level of instantaneous utility. On the producer side, the discovery of an innovation gives one firm temporary monopoly profits until the next innovation occurs and it is driven out of business.

In the model, a fall in tariffs shifts labor from the nontraded good sector (sector 0 for country 1) to the exported good sector (sector 1 for country 1). In particular, it reduces the amount of labor devoted to R\&D services in the nontraded sector and increases the amount of labor devoted to R\&D services in the export sector. Similarly, a reduction in the tariff rate leads to a fall in the amount of labor devoted to final output production in the nontraded sector, and increases the amount of labor expended on final output production in the export sector. Finally, a reduction in tariffs also leads to a decrease in steady-state expenditure on country $i$ 's nontraded good and leads to an increase in steady-state expenditure on country i's exported good. Thus, by changing the level of tariffs, the government can reallocate labor in the country. The government's decision concerning the optimal level of tariffs to set is explained below. 


\section{Determining the Government's Optimal Level of Tariffs}

The government in each country $i$ sets the level of tariffs on good $j$, (where $T=1+\tau$ ) at every time period $t$. It also keeps a proportion $f$ of tariff revenues and gives the remaining $(1-f)$ of tariff revenues to consumers as a lump sum. The costs associated with the collection process are $\beta c_{t}$, where $\beta$ is a constant, $c(0)=0, c^{\prime}(0) \geq 0, c^{\prime} \geq 0$, and $c^{\prime \prime} \geq$ 0 . Here, we propose that the costs of collecting tariffs reflect the quality of institutions in that country-countries with better institutions should face higher costs of collecting tariff revenues than those with poor institutions. The government also faces political instability due to the process of innovation. Thus, if the probability of the government being overthrown every time there is an innovation is $(1-\mu)$, the probability of maintaining power each time an innovation occurs is $\mu$.

The key idea above is that governments may find domestic innovation politically destabilizing. The reasons for this are discussed in Chaudhry and Garner (2007):

In general, we can think of three ways in which innovation can politically threaten the current government. First, the nature of the innovation itself could be threatening. Information technologies like printing, satellite dishes, and the Internet could spread information that could induce political instability, especially in repressive regimes that attempt to control the population through ideology, etc. This mechanism is appealing, but unfortunately no simple way of modeling it presents itself. Second, innovations in the private sector could also shift economic power to groups that are unfavorable to the current regime. As economic power often translates into political power, these groups could try to replace the current government. Third, there may be vested interests that oppose the adoption of a new innovation.

Given the setup of the model above, it can be shown that country $1^{\prime}$ 's real revenues from tariffs are $[(T-1) / T]\left[\alpha_{2} / \alpha_{0}\right] Y_{0}^{1} / w^{1}$, which means that the government's expected wealth in the steady state can be written as

$$
E\left(W_{t}\right)=\int_{0}^{\infty} e^{-\rho t}\left\{\left[\left[\frac{f(T-1)}{T}\right]\left[\frac{\aleph_{2}}{\propto_{0}}\right] Y_{0}^{1} / w^{1}-\beta c_{t}\right]\right\} P r_{v} d t
$$

$P r_{v}$ is the probability of being in power at time $t$. 
If the number of innovations that have occurred up to time $t$ in sector 0 is represented by $s$, and the number of innovations that have occurred up to time $t$ in sector 1 is represented by $v$, the expression is rewritten as

$E\left(W_{t}\right)=\int_{0}^{\infty} e^{-\rho t}\left\{\sum_{s=0}^{\infty} \sum_{v=0}^{\infty} \Pi(s, t) \prod(v, t)\left[f \tilde{Y}-\beta c_{t}\right] \mu^{s+v}\right\} d t$

Where $\tilde{Y}=[(T-1) / T]\left[\alpha_{2} / \alpha_{0}\right] Y_{0}^{1} / w^{1}$,

$\Pi(\mathrm{s}, \mathrm{t})=\frac{\left(\lambda n_{0}^{1} t\right)^{s}}{s !}+e^{-\lambda n_{0}^{1} t}$ is the probability that there will be exactly $s$ innovations up to time $t$ in sector 0 , and $\Pi(\mathrm{v}, \mathrm{t})=\frac{\left(\lambda n_{1}^{1} t\right)^{v}}{s !} e^{-\lambda n_{0}^{1} t}$ is the probability that there will be exactly $v$ innovations up to time $t$ in sector 1 .

The above expression reduces to

$$
E\left(W_{t}\right)=\frac{f \tilde{Y}-\beta c_{t}}{\rho-(\mu-1)\left(\lambda n_{0}^{1}+\lambda n_{1}^{1}\right)}
$$

\section{A. Determination of the Government's Optimal Level of Tariffs}

The government chooses that level of tariffs that optimizes its rent collection. The maximization problem it solves is

$$
\operatorname{Max}_{T} \frac{f \tilde{Y}-\beta c_{t}}{\rho-(\mu-1)\left(\lambda n_{0}^{1}+\lambda n_{1}^{1}\right)}
$$

After plugging in from Equation (19), this simplifies to

$$
\operatorname{Max}_{T} \frac{f\left[\frac{\alpha_{2}(T-1)}{\left(\alpha_{0}+\alpha_{1}\right) T+\alpha_{2}}\right]\left[L^{1}+2 \rho / \lambda\right]-\beta c_{t}}{\rho-(\mu-1)\left(\lambda n_{0}^{1}+\lambda n_{1}^{1}\right)}
$$

The first-order condition we obtain is

$$
f \widetilde{Y^{\prime}}-\beta c^{\prime}{ }_{t}+\frac{\left(f \widetilde{Y}-\beta c_{t}\right)(\mu-1)\left[\lambda\left(\partial n_{0}^{1} / \partial T\right)+\lambda\left(\partial n_{1}^{1} / \partial T\right)\right]}{\rho-(\mu-1)\left(\lambda n_{0}^{1}+\lambda n_{1}^{1}\right)}
$$

It is useful to analyze this equation in greater detail. The first term $f \widetilde{Y}$ is the expected marginal benefit of raising the tariff rate on tariff revenues. It can be shown that this term is positive. The second term is the expected marginal cost of raising the tariff rate, and is negative by assumption. The sign of the third term is dependent on the sign of $\lambda\left(\partial n_{0}^{1} / \partial T\right)+\lambda\left(\partial n_{1}^{1} / \partial T\right)$. By differentiating Equations (19) with respect 
to $T$, it can be shown that an increase in the tariff rate leads to an increase in the R\&D labor in sector $0\left(\partial n_{0}^{1} / \partial T>0\right)$ and a decrease in the amount of R\&D labor in sector $1\left(\partial n_{1}^{1} / \partial T<0\right)$.

If one assumes that the export sector $j$ is characterized by larger innovations, or $\gamma_{i}>\gamma_{0}$, it can be shown that $\left[\lambda\left(\partial n_{0}^{1} / \partial T\right)+\lambda\left(\partial n_{1}^{1} / \partial T\right)\right]<0$ . Based on this assumption, the third term is positive, which means that the government gains an extra benefit from raising tariffs.

Given the first-order equation, we can define $F$ as

$$
=f \widetilde{Y}^{\prime}-\beta c^{\prime}{ }_{t}+\frac{\left(f \widetilde{Y}-\beta c_{t}\right)(\mu-1)\left[\lambda\left(\partial n_{0}^{1} / \partial T\right)+\lambda\left(\partial n_{1}^{1} / \partial T\right)\right]}{\rho-(\mu-1)\left(\lambda n_{0}^{1}+\lambda n_{1}^{1}\right)}
$$

From this we can obtain the optimal tariff level that the government sets, $T^{*}$, which implicitly solves $F=0$ in Equation (24).

\section{Results}

\subsection{Setting Optimal Tariffs}

Equation (24) gives rise to the following proposition.

Proposition 1: Given that an interior solution to the government's maximization problem exists:

The greater the threat of political instability by innovation, the greater the tariff rate set by the government. $\left(\partial T^{*} / \partial \mu<0\right)$

The greater the costs associated with the collection of tariffs, the lower the tariff rate set by the government. $\left(\partial T^{*} / \partial \beta<0\right)$

See Appendix A for the formal proof.

Part (a) of the proposition provides an interesting interpretation of the role of tariffs in an economy. As in other models, a tariff is used as a rent-extracting device, but unlike in other models, it is also used to block innovation by shifting labor from the sector with a larger level of innovations (the export sector) to the sector with a smaller level of innovations (the nontraded sector). Thus, when faced with a greater risk of losing power (due to levels of innovation), a government will tend to block innovation by collecting greater rents (raising the tariff rate). A government that is not as politically threatened by innovation will keep the tariff rate lower and allow a greater degree of innovation. 
Part (b) of the proposition should be intuitive. If the costs of collecting tariff revenues increase, then the government will decrease the tariff rate it sets. It is important to note that the exact tariff rate, $T^{*}$, that is set depends on all the parameters above. So, if the costs associated with collecting tariffs are high enough, even an unstable government may choose to set lower tariffs. Since the costs of collecting tariffs reflect the quality of that country's institutions, countries with better institutions should decrease their tariff rate.

\subsection{Steady-State Growth}

To calculate the growth rate of country i, we define its long-run growth rate as the change in country 1's expected steady-state instantaneous utility, $\ln \left(u^{1}\right)$. Following Dinopoulos and Syropoulos, this is given by

$$
\begin{aligned}
& G=\alpha_{0} \lambda^{1} n_{0}^{1} \ln \left(\gamma_{0}\right)+\alpha_{1} \lambda^{1} n_{1}^{1} \ln \left(\gamma_{1}\right)+\alpha_{2} \lambda^{2} n_{2}^{2} \ln \left(\gamma_{2}\right) \\
& G=\alpha_{0} R_{0}^{1} \ln \left(\gamma_{0}\right)+\alpha_{1} R_{1}^{1} \ln \left(\gamma_{1}\right)+\alpha_{2} R_{2}^{2} \ln \left(\gamma_{2}\right)
\end{aligned}
$$

Before analyzing the effects of trade liberalization on growth, we define the "growth intensity" $\Gamma_{j}$ of sector $j$ as

$$
\Gamma_{j}=\alpha_{j} \lambda\left(1-1 / \gamma_{j}\right) \ln \left(\gamma_{j}\right) \quad \forall j=0,1,2
$$

This intensity measures the contribution to growth of each sector $j$ in the economy. Sectors with large expenditure shares $\left(\alpha^{\prime} s\right)$ and a larger level of innovations have higher growth intensities. Our model assumes that expenditure shares are the same for the nontraded sector (0) and the export sector $i$, whereas the export sector has a larger level of innovations, $\gamma_{\mathrm{i}}>\gamma_{0}$. Thus, the export sector's growth intensity is greater than that of the nontraded sector, i.e., $\Gamma_{1}>\Gamma_{0}$.

The main results of the section are given below.

Proposition 2: Given that the share of expenditures on the nontraded good is greater than 0 :

(a) If the export sector's growth intensity is greater than that of the nontraded sector, a reduction in the tariff rate of country $i$-due to an improvement in the quality of its institutions-will lead to an increase both in the amount of trade and the growth of country $i$, If the export sector's growth intensity is lower than that of the 
nontraded sector, a reduction in the tariff rate of country $i$ will lead to a decrease both in the amount of trade and the growth rate of country $i,\left(\partial G^{i} / \partial T^{i}<0\right)$

If the export sector's growth intensity is greater than that of the nontraded sector, a reduction in the tariff rate of country $j$-due to an improvement in the quality of its institutions-will lead to an increase in the growth rate of country $i,\left(\partial G^{i} / \partial T^{j}<0\right)$

See Appendix A for the formal proof.

Part (a) of this proposition presents the effects of tariff reductions on a particular country's growth rate. As shown in the manner in which the government determines an optimal tariff rate, different parameters of the model can lead to decreases in the tariff rate set by the government. So, a decrease in the threat of political instability or an increase in the costs of tariff revenue collection can cause a country's government to lower its tariff rate. This redistributes labor from the nontraded sector to the export sector, and results in an increase in country $i$ 's quantity of trade. Also, if the export sector is more growth-intensive than the nontraded sector-as is assumed in this model-then the redistribution of labor toward the export sector will raise the economy's growth rate.

At this stage, one should note that this proposition depends on the assumption that the export sector's growth intensity should be greater than that of the domestic nontraded sector. As discussed in the introduction, if the domestic nontraded sector has larger growth intensity-due to greater innovations in the sector-then higher tariffs would lead to lower growth. This could be the relevant case for the late 19th century. While the interpretation of our results has focused on the export sector as the "growth engine," the model is flexible enough to allow for this alternative.

Part (b) of the proposition states that a decrease in the tariff rate of country $j$ leads to an increase in the growth rate of country $i$. This is because a reduction in country $j^{\prime}$ s tariffs increases R\&D investment in country $j$ 's export sector (as discussed in Section 2), which in turn reduces the world price of its exported good and leads to an increase in the longrun growth rate of its trading partner. Thus, there exist "institutional spillovers" from one country to another in this model, due to the effect that institutions have on tariffs. 


\subsection{Trade and Growth}

The model presented above also has interesting implications for the relationship between trade and growth in the presence of good and bad institutions. The reason for analyzing the relationship between trade and growth-as opposed to simply concentrating on the relationship between tariffs and growth-is that trade restrictions can take on forms other than simple tariff restrictions. In addition to quota restrictions, the government can also limit imports through mechanisms such as foreign exchange and licensing controls. However, all these methods of controlling imports will affect a country's quantity of trade, which is more easily observed. The aim of this section is to see how institutional quality can affect the relationship between trade and growth.

Two basic results determine the relationship between trade and growth. The first is an obvious extension of the propositions above: If the quality of a country's institutions improves, the government will set a lower tariff rate, which will lead to higher growth rates. Thus, institutional quality has a direct impact on trade and growth-better institutions (and the accompanying lower tariffs) lead to higher trade and higher growth.

The second result focuses on the relationship between trade and growth for countries with either strong or weak institutions. In this section, we keep the level of tariffs fixed because we want to compare how trade affects growth in a country with good institutions as opposed to a country with bad institutions. But since changes in trade will alter the optimal tariff rate set by the government, there may be some confusion as to the effect of trade on growth.

An example may help illustrate the problem: If the quantity of labor in the economy rises, the government will have an incentive to change the tariff rate in the economy. It can be shown that, if the labor supply increases, then the optimal tariff rate set by the government also increases. Thus, while trade by itself leads to higher growth, higher tariffs will reduce the growth rate. To isolate the effect of trade on growth with fixed levels of institutions, we assume in this section that tariffs are fixed. This is achieved by assuming that there are two countries: one with very high institutional quality (a very high cost of tariffs, $c$ ), and another with very low levels of institutional quality (a very low cost of tariffs, $c$ ). The first country will set its tariff rate close to 0 , whereas the second will set its tariff rate close to 1 . Then, if the labor supply in the country with good institutions increases, the cost of tariff collection is so high that the level of tariffs does not change. 
To observe the effect of higher trade on growth, one has to focus on the equilibrium level of trade. It can be shown that the total trade in country $i$-which is the sum of domestic expenditure on imports and domestic revenues for exports-is given by

$$
\text { Trade }=\frac{2 \alpha_{2}}{T\left(\alpha_{0}+\alpha_{1}\right)+\alpha_{2}}\left(L^{i}+\rho / \theta_{0}+\rho / \theta_{i}\right)
$$

As discussed above, one way for the country's total trade to rise would be for it to decrease its tariff rate. Another way to increase trade would be to increase the amount of labor in the economy $\left(L^{i}\right)$. Thus, an economy with more consumers would trade more, for a given level of tariffs.

The next question to ask is how this trade would affect the growth rate. Using the definition of the growth rate given above (in Equation 25), we obtain the following proposition.

Proposition 3: Given that total trade is the sum of domestic expenditure on imports and domestic revenues from exports:

a) For a given level of tariffs, an increase in the quantity of labor in country $i$ will lead to an increase in its total trade and growth rate, (DTrade $\left./ \partial L^{i}>0\right)$

b) Countries with stronger institutions will experience larger increases in growth than countries with weaker institutions, $\left(\partial^{2} G / \partial L^{i} \partial \mathrm{T}>0\right)$

Countries with stronger institutions will experience larger increases in growth than countries with weaker institutions

See Appendix A for the formal proof.

Part (a) shows how an increase in one country's labor force stock leads to higher trade and higher growth for all countries. This should be intuitive since an increase in labor stock leads to an increase in the amount of labor in the R\&D sectors of the traded and nontraded goods. This, in turn, leads to higher growth. Part (b) discusses how institutional quality influences the relationship between trade and growth, and can be illustrated with an example: Take two countries with different institutional qualities. Both experience increases in their labor stocks and increased trade. From part (a), we know that this will lead to higher growth in both countries, but the incremental growth in the country with better institutions should be higher than the incremental growth in the 
country with poorer institutions. Thus, the institutional quality of a country affects the increase in growth due to the increase in trade.

The main finding of this section is that higher trade is accompanied by higher growth for all countries, but that countries with better institutions experience greater increases in their growth rates than countries with weaker institutions.

\section{Conclusion}

This article shows how institutions, innovations, and political stability affect tariffs in an economy and, in turn, affect growth. Good institutions should lead to lower tariffs and tariffs and, in turn, affect growth rates. However, the relationship between tariffs and growth is not as obvious. We find that, if a country has a technologically dynamic export sector (characterized by large innovations), higher tariffs reduce growth by channeling labor away from R\&D in the export sector. On the other hand, in a country with a technologically dynamic domestic production sector, higher tariffs may lead to higher growth.

Besides the impact that tariffs have on the domestic growth rate, we show that tariffs should also have an impact on the growth rate of a country's trading partners. In particular, lower tariffs in one country should lead to higher growth rates for its trading partners. This result has important implications for institutional spillovers. If the institutional quality of one country improves, it leads to lower tariffs in that country, which increases the growth rates of its trading partners. But again, this result does not hold if the trading partner has a technologically dynamic domestic production sector.

Finally, we also find that trade should lead to accelerated growth. In particular, while trade leads to higher growth rates in countries that have both good and poor institutions, countries with good institutions should experience more incremental growth than those with poor institutions.

At this stage it is important to note two things. First, in reality, institutions should affect growth through many channels other than tariffs. The aim of our model, however, is not to present tariffs as the only channel through which institutions affect growth, but rather to isolate the impact of institutions on tariffs and economic growth. Second, tariffs are determined by many more factors than just institutions. But again, the link between tariffs and institutions has been ignored in the past and our findings provide a direction for further research in this area. 


\section{References}

Acemoglu, D., Johnson, S., \& Robinson, J. (2001). The colonial origins of comparative development: An empirical investigation. American Economic Review, 91(5), 1369-1401.

Aghion, P., \& Howitt, P. (1992). A model of growth through creative destruction. Econometrica, 60(2), 323-351.

Aghion, P., \& Howitt, P. (1999). Endogenous growth theory. Cambridge, MA: MIT Press.

Barro, R. (1997). Determinants of economic growth: A cross-country study. Cambridge, MA: MIT Press.

Broadberry, S. (1998). How did the United States and Germany overtake Britain? A sectoral analysis of comparative productivity levels, 1870-1990. Journal of Economic History, 58(2), 375-407.

Chaudhry, A., \& Garner, P. (2006). Political competition between countries and economic growth. Review of Development Economics, $10(4), 666-682$.

Chaudhry, A., \& Garner, P. (2007). Do governments suppress growth? Institutions, rent seeking, and innovation blocking in a model of Schumpeterian growth. Economics and Politics, 19(1), 35-52.

Clemens, M., \& Williamson, J. (2001). A tariff growth paradox? Protection impact the world around 1875-1997 (Working Paper No. 8459). Cambridge, MA: National Bureau of Economic Research.

Dinopoulos, E., \& Segerstrom, P. (1999). A Schumpeterian model of protection and relative wages. American Economic Review, 89(3), $450-472$.

Dinopoulos, E., \& Syropoulos, C. (1997). Tariffs and Schumpeterian growth. Journal of International Economics, 42, 425-452.

Dinopoulos, E., \& Syropoulos, C. (1999). Innovation-blocking activities in the theory of Schumpeterian growth. [Working Paper]. Department of Economics, University of Florida. 
Garner, P. (2001). The role of international rivalry in long-run growth. [Mimeo]. Brown University, RI.

Grossman, G., \& Helpman, E. (1993). Innovation and growth in the global economy. Cambridge, MA: MIT Press.

Grossman, G., \& Helpman, E. (1994). Protection for sale. American Economic Review, 84(4), 833-850.

Hillman, A. (1982). Declining industries and political support protectionist motives. American Economic Review, 72, 1180-1187.

Knack, S., \& Keefer, P. (1995). Institutions and economic performance: Cross-country tests using alternative measures. Economics and Politics, 7, 207-227.

North, D. (1990). Institutions, institutional change and economic performance. Cambridge, UK: Cambridge University Press.

O' Rourke, K. (2000). Tariffs and growth in the late 19th century. Economic Journal, 110, 456-483.

Rodriguez, F., \& Rodrik, D. (1999). Trade policy and economic growth: A skeptic's guide to the cross-national evidence (Working Paper No. 7081). Cambridge, MA: National Bureau of Economic Research.

Sachs, J., \& Warner, A. (1995). Economic reform and the process of global integration. Brookings Papers on Economic Activity, 1, 1-118. 


\section{Appendix A}

\section{Proof of Proposition 1}

Part (a): We need to show that, for $T^{*}>0, \frac{\partial T^{*}}{\partial \mu}<0$

From the implicit function theorem (with the appropriate regularity conditions) we know that

$$
\frac{\partial T^{*}}{\partial \mu}=-\frac{\partial F}{\partial \mu} / \frac{\partial F}{\partial T^{*}}
$$

Here, it is important to note that $\frac{\partial F}{\partial T^{*}}$ is simply the second-order condition for the government's rent maximization problem. It can be shown that there exists a $\bar{T}$, such that, for any $T>\bar{T}, \frac{\partial F}{\partial T}<0$. Therefore, we need to show that $\frac{\partial F}{\partial \mu}<0$.

Recalling that $F=f . \partial \tilde{Y} / \partial T-\beta . \partial c_{t} / \partial T+\frac{\left(f \tilde{Y}-\beta c_{t}\right)(\mu-1)\left[\lambda\left(\partial n_{0} / \partial T\right)+\lambda\left(\partial n_{i}^{i} / \partial T\right)\right]}{\rho-(\mu-1)\left(\lambda n_{0}+\lambda n_{i}\right)}$ :

$$
\begin{aligned}
& \frac{\partial F}{\partial \mu}=\frac{\left(f \tilde{Y}-\beta c_{t}\right)\left[\lambda\left(\partial n_{0} / \partial T\right)+\lambda\left(\partial n_{i}^{i} / \partial T\right)\right]}{\rho-(\mu-1)\left(\lambda n_{0}+\lambda n_{i}\right)} \\
& +\frac{\left(f \tilde{Y}-\beta c_{t}\right)(\mu-1)\left[\lambda\left(\partial n_{0} / \partial T\right)+\lambda\left(\partial n_{i}^{i} / \partial T\right)\right]\left[\lambda n_{0}^{i}+\lambda n_{i}^{i}\right]}{\left[\rho-(\mu-1)\left(\lambda n_{0}+\lambda n_{i}\right)\right]^{2}}
\end{aligned}
$$

This can be written as:

$$
\frac{\partial F}{\partial \mu}=\frac{\left(f \tilde{Y}-\beta c_{t}\right)\left[\lambda\left(\partial n_{0}^{i} / \partial T\right)+\lambda\left(\partial n_{i}^{i} / \partial T\right)\right]}{\rho-(\mu-1)\left(\lambda n_{0}+\lambda n_{i}\right)}\left[1+\frac{(\mu-1)\left[\lambda n_{0}^{i}+\lambda n_{i}^{i}\right]}{\rho-(\mu-1)\left(\lambda n_{0}+\lambda n_{i}\right)}\right]
$$

This will be less than zero (keeping in mind that $\left[\lambda\left(\partial n_{o}^{i} / \partial T\right)+\right.$ $\lambda \partial n i i \partial T<0$ and $\mu-1<0$ ) if:

$$
\begin{aligned}
& {\left[1+\frac{(\mu-1)\left[\lambda n_{0}^{i}+\lambda n_{i}^{i}\right]}{\rho-(\mu-1)}\left(\lambda n_{0}^{i}+\lambda n_{i}^{i}\right)\right]>0} \\
& \Rightarrow \rho-(\mu-1)\left(\lambda n_{0}^{i}+\lambda n_{i}^{i}\right)+(\mu-1)\left[\lambda n_{0}^{i}+\lambda n_{i}^{i}\right]>0 \\
& \Rightarrow \rho>0
\end{aligned}
$$


Which is true by assumption.

Part (b) We need to show that for $T^{*}>0, \frac{\partial T^{*}}{\partial \beta}<0$

For $T^{*}>0$, we have an interior solution so that $\frac{\partial F}{\partial T}<0$. Therefore we need to show that

$$
\begin{aligned}
& \frac{\partial F}{\partial f}<0 . \\
& \frac{\partial F}{\partial \beta}=-\partial c_{t} / \partial T-\frac{\left(c_{t}\right)(\mu-1)\left[\lambda\left(\partial n_{o}^{i} / \partial T\right)+\lambda\left(\partial n_{i}^{i} / \partial T\right)\right]}{\rho-(\mu-1)\left(\lambda n_{0}^{i}+\lambda n_{i}^{i}\right)}<0 .
\end{aligned}
$$

\section{Proof of Proposition 2}

Part (i) We need to show that for $T>0, \frac{\partial G}{\partial T}<0$.

$$
\begin{gathered}
\partial G^{i} / \partial T^{i}=\left(\lambda \alpha_{0} \ln \gamma_{0}\right)\left(1-1 / \gamma_{0}\right)\left(L^{i}+2 \rho / \lambda\right)\left(\frac{\alpha_{0} \alpha_{2}}{\left[\left(\alpha_{0}+\alpha_{1}\right) T+\alpha_{2}\right]^{2}}\right) \\
-\left(\lambda \alpha_{1} \ln \gamma_{1}\right)\left(1-1 / \gamma_{1}\right)\left(L^{i}+2 \rho / \lambda\right)\left(\frac{\alpha_{0} \alpha_{2}}{\left[\left(\alpha_{0}+\alpha_{1}\right) T+\alpha_{2}\right]^{2}}\right) \\
\partial G^{i} / \partial T^{i}=\left[\left(\lambda \alpha_{0} \ln \gamma_{0}\right)\left(1-1 / \gamma_{0}\right)-\left(\lambda \alpha_{1} \ln \gamma_{1}\right)\left(1-1 / \gamma_{1}\right)\right]\left(\frac{\alpha_{0} \alpha_{2}}{\left[\left(\alpha_{0}+\alpha_{1}\right) T+\alpha_{2}\right]^{2}}\right)
\end{gathered}
$$

Recall that the first term is the bracket was defined as the growth intensity, $\Gamma_{0}$, of sector 0 , and the second term was defined as the growth intensity, $\Gamma_{1}$, of sector 1 . It was assumed that $\Gamma_{1}>\Gamma_{0}$ :

$\partial G / \partial T=\left[\Gamma_{0}-\Gamma_{1}\right]\left(\frac{\alpha_{0} \alpha_{2}}{\left[\left(\alpha_{0}+\alpha_{1}\right) T+\alpha_{2}\right]^{2}}\right)<0$

Part (b) We need to show that $\partial^{2} G^{i} / \partial T^{j}<0$.

From Equation (25) we know that:

$$
\partial G^{i} / \partial T^{j}=\frac{\partial\left(\alpha_{2}^{j} \ln \gamma_{2}\left(R_{2}^{j}\right)\right)}{\partial T_{j}}=\alpha_{2}^{j} \ln \gamma_{2} \frac{\partial R_{2}^{j}}{\partial T^{j}}
$$

From Part (a) we know that $\frac{\partial R_{2}^{j}}{\partial T^{j}}<0$, implying that 
Which implies that: $\partial^{2} G^{i} / \partial T^{j}<0$.

\section{Proof of Proposition 3}

Part (a) we need to show that $\partial(\operatorname{Trade}) / \partial L^{i}>0$

From Equation (26) we know that:

$$
\text { Trade }=\frac{2 \alpha_{2}}{T\left(\alpha_{0}+\alpha_{1}\right)+\alpha_{2}}\left(L^{i}+2 \rho / \lambda\right)
$$

Which implies that: $\frac{\partial(\text { Trade })}{\partial L^{i}}=\frac{2 \alpha_{2}}{T\left(\alpha_{0}+\alpha_{1}\right)+\alpha_{2}}>0$.

From Equation (25):

$$
\frac{\partial G^{i}}{\partial L^{i}}=\alpha_{0} \frac{\partial R_{0}^{i}}{\partial L^{i}} \ln \left(\gamma_{0}\right)+\alpha_{i} \frac{\partial R_{i}^{i}}{\partial L^{i}} \ln \left(\gamma_{i}\right)
$$

From the definitions of $R_{0}^{1}$ and $R_{i}^{i}$, it can be shown that $\frac{\partial R_{0}^{i}}{\partial L^{i}}>0$ and $\frac{\partial R_{i}^{i}}{\partial L^{i}}>0$.

This implies that: $\frac{\partial G^{i}}{\partial L^{i}}>0$.

Part (b) we need to show that $\frac{\partial^{2} G^{i}}{\partial L^{i} \partial T}<0$

In part (a), we showed that:

$$
\frac{\partial G^{i}}{\partial L^{i}}=\alpha_{0} \frac{\partial R_{0}^{i}}{\partial L^{i}} \ln \left(\gamma_{0}\right)+\alpha_{i} \frac{\partial R_{i}^{i}}{\partial L^{i}} \ln \left(\gamma_{i}\right)
$$

This implies that $\frac{\partial^{2} G^{i}}{\partial L^{i} \partial T}=\alpha_{0} \frac{\partial^{2} R_{0}^{i}}{\partial L^{i} \partial T} \ln \left(\gamma_{0}\right)+\alpha_{i} \frac{\partial^{2} R_{i}^{i}}{\partial L^{i} \partial T} \ln \left(\gamma_{i}\right)$

We can show that $\frac{\partial^{2} R_{0}^{i}}{\partial L^{i} \partial T}>0$ and $\frac{\partial^{2} R_{i}^{i}}{\partial L^{i} \partial T}<0$

Recalling the definition of the growth intensity, $\Gamma_{j}$ and the assumption that $\Gamma_{1}>\Gamma_{0}$, the negative growth impact in sector 1 will dominate the positive growth impact in sector 0 .

This implies that: $\frac{\partial^{2} G^{i}}{\partial L^{i} \partial T}<0$ 


\section{Appendix B}

Figure 1

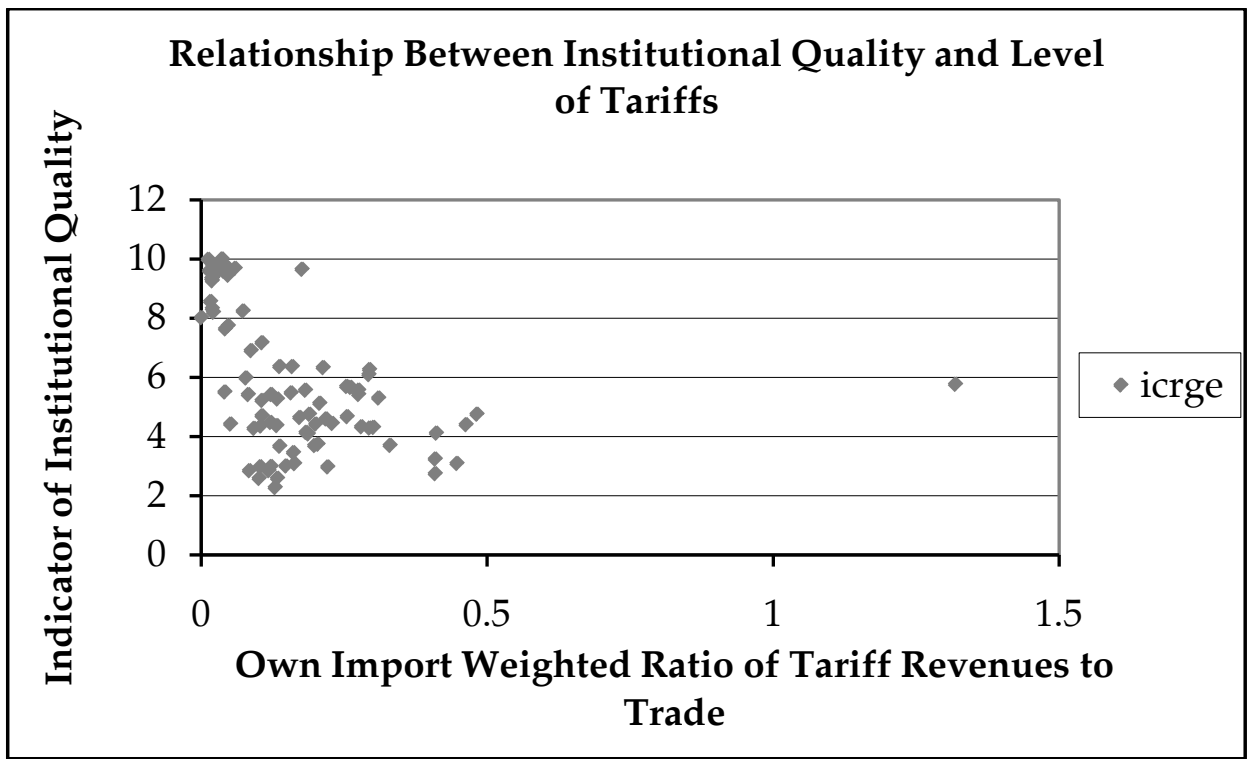

Figure 2

Relationship between Growth Rates and Tariff levels

(1875-1914)

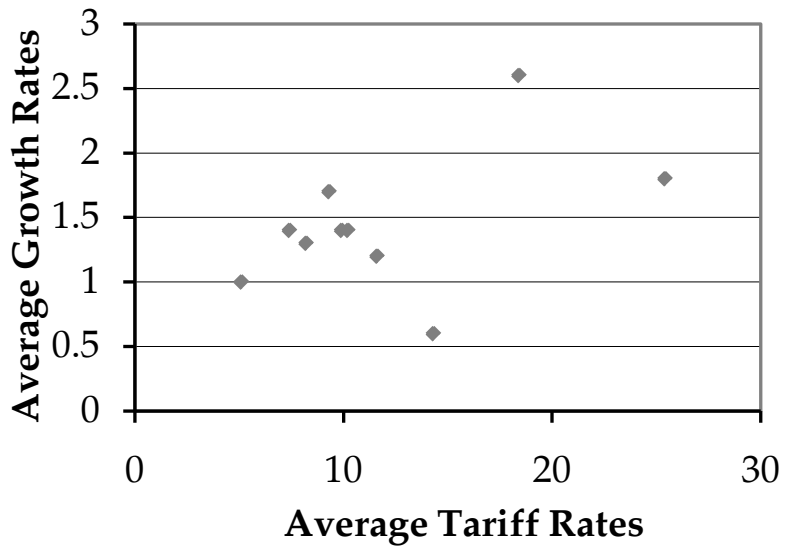

- Average Growth Rates 